\title{
Valuing Our National Parks: An Ecological Economics Perspective
}

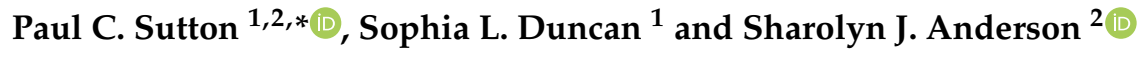 \\ 1 Department of Geography and the Environment, University of Denver, Denver, CO 80208, USA; \\ sophialduncan@gmail.com \\ 2 School of Natural and Built Environments, University of South Australia, Adelaide, SA 5000, Australia; \\ sharolyn.anderson@unisa.edu.au \\ * Correspondence: paul.sutton@du.edu; Tel.: +01-303-871-2399
}

Received: 25 March 2019; Accepted: 26 March 2019; Published: 29 March 2019

\begin{abstract}
The annual budget for the United States National Park Service was roughly $\$ 3$ billion in 2016. This is distributed amongst 405 National Parks, 23 national scenic and historic trails, and 60 wild and scenic rivers. Entrance fees and concessions generate millions of dollars in income for the National Park Service; however, this metric fails to account for the total value of the National Parks. In failing to consider the value of the ecosystem services provided by the National Parks, we fail to quantify and appreciate the contributions our parks make to society. This oversight allows us to continue to underfund a valuable part of our natural capital and consequently damage our supporting environment, national heritage, monetary economy, and many of our diverse cultures. We explore a simple benefits transfer valuation of the United States' national parks using National Land Cover Data from 2011 and ecosystem service values determined by Costanza et al. This produces an estimate suggesting the parks provide $\$ 98$ billion/year in ecosystem service value. If the natural infrastructure 'asset' that is our national park system had a budget comparable to a piece of commercial real estate of this value, the annual budget of the National Park Service would be roughly an order of magnitude larger at something closer to $\$ 30$ billion rather than $\$ 3$ billion.
\end{abstract}

Keywords: National Parks; ecosystem service value; natural capital; Green New Deal

\section{Introduction}

The national parks can be regarded as an asset of natural capital. Traditional capital assets are frequently valued in dollars; however, estimating the dollar value of natural capital (e.g., the National Parks) is fraught with complexity and uncertainty. We provide an economic estimate of the annual value of ecosystem services provided by this natural capital asset to present an argument for more substantial investment in the maintenance and preservation of our parks. This economic valuation of the ecosystem services provided annually by the national parks is based on a simple direct benefits transfer analysis using landcover data and values per biome associated with the respective landcovers [1]. This estimate includes both economic and non-economic values provided by the functioning ecosystems of the national parks. In addition, the value of ecosystem services are sometimes perceived by the public yet often not perceived (e.g., the value of nutrient cycling by soil biota is often not perceived or appreciated by the public [2]). Ecosystem services provided by nature have many market failure properties including unclear property rights, public good nature, externalities, and common pool resources. Consequently, these estimates of value are not intended to enable commodification of ecosystem services or the natural capital assets that generate them. 


\subsection{Economic and Non-Economic Value of the United States' National Parks}

More than 275 million people visit "America's best idea" every year [3]. From the swampy Everglades, reminiscent of the age of dinosaurs, to the purple mountains of Rocky Mountain National Park, the National Parks protect our natural wonders. The social impact of our National Parks is manifold; Americans and foreigners alike can immerse themselves in history at our battlefields and National Historic Sites, and leave their cities of origin to find themselves truly in the wild in parks and National Monuments.

The financially measurable economic impact of our parks is significant. Concessioners within the National Parks generate $\$ 1.3$ billion in revenue every year, and pay $\$ 80$ million in franchise fees to the federal government [4]. Communities near the National Parks also depend on park visitation to sustain nearly 300,000 local jobs; these visitors contribute $\$ 32$ billion to the U.S. economy [4]. The influence of the National Parks reaches beyond their physical boundaries. National Park tours contribute to the international travel industry. Small towns that are "on the way" to the parks also benefit from the traffic that runs through them [4].

There are many ways to attribute value to the National Park Service. Some traditional approaches are metrics like number of visitors, concessioner profits, and job growth; however, these approaches focus primarily on the transactional economic activities taking place in or near our National Parks and are used as a proxy measure of value [4]. Ecosystem services are the benefits we receive from functioning ecosystems [5]. Examples of ecosystem services include four broad categories: (1) provisioning services (production of food, fiber, and timber), (2) regulating services (e.g., water filtration and climate regulation), (3) supporting services (e.g., nutrient cycling) and (4) cultural services (e.g., recreation, aesthetic inspiration, and cultural identity) [6].

Human wellbeing results from the interaction of ecosystem services with human, social, natural, and built capital [7]. The ways that individuals, communities, and their built environments interact with natural capital is how we reap the benefits of ecosystem services [8]. Ecosystem services and natural capital suffer from many market failure properties including the following: they suffer from both positive and negative externalities, they have unclear property rights, many are open access regimes, and they are often public goods [9]. Estimates of the economic value of ecosystem services suggest their value is almost twice as large as the entire global market economy, which precludes any policy attempts to internalize the costs of any externalities associated with damaging ecosystem functions and or services [10]. Because of the many market failure qualities of ecosystem services we argue that structuring the ways our built and social environments interact with ecosystem services is not best optimized by free market principles and policies. Making shifts in the arrangements of social, human, built, and natural capital will likely prove to be quite difficult because preliminary studies in South Australia suggest that those trained in the dominant economic paradigm (people employed in finance, management, and business) have significantly lower levels of ecological literacy [11].

Economic valuation of ecosystem services is often perceived as a way to commodify natural capital thus enabling the preservation of neo-classical economic policy for the 'management' of nature. The immense value of ecosystem services relative to the market economy, in addition to their aforementioned market failure properties, suggest that current environmental challenges result from a failure of governance [12]. Market failures are generally recognized to be an appropriate domain of government intervention. Sustainable and desirable stewardship of our environmental endowment (including our national parks) will likely require new institutions utilizing broader holistic policies, using longer time horizons, and associating significantly higher values to ecosystem services than are currently provided by market-based assessments [13].

\subsection{Valuation Is Not Commodification}

We explore a simple economic valuation of the lands that exist in the National Parks of the United States using a benefits transfer methodology. There are many criticisms of the very idea of placing an economic value on nature that have undoubtedly contributed to the distracting debate on the 
difference (or lack thereof) between the idea of Ecosystem Services and 'Nature's Contribution to People' $[14,15]$. One fundamental criticism from the 'you simply underestimated infinity' school of thought is that any finite estimate of the value of natural capital is an underestimate because the 'consumer surplus' of nature is infinite—or at least 'all that we could possibly pay'-because without natural capital there is no society, no built capital, no human capital, and no economy at all. While this is true, infinity is not a useful number to use when making decisions about the allocation of resources. Failure to appropriately value natural capital and ecosystem services has resulted in lost ecosystem services due to land degradation ( $\sim \$ 6$ trillion/year [9]) and land cover change ( $\sim 20$ trillion/year [7]). These losses are massive relative to the size of the global market economy and suggest that 'business as usual' free market policies will continue to fail.

In a period of political, economic, and social uncertainty, the future of our National Parks hangs in the balance. Ecosystem service valuation provides a method of valuing our Natural Parks that can be useful in resource allocation decisions and enhance a more comprehensive appreciation of their value and the benefits we derive from them. The process of ecosystem service valuation should not be confused with the commodification of nature. Many ecosystem services are non-rival, meaning a large number of people can enjoy a hiking trail at a National Park without impairing others' enjoyment [16]. However, when Parks are supplied in such a manner as to be frequently congested, we cause many problems including: degradation of the parks themselves, impaired experiences of park visitors, and reduced public access to nature that is likely to be controlled by pricing mechanisms that are likely to increase the inequality of access to a public resource. Many ecosystem services are also non-excludable; using the National Parks as an example, the benefits of forests filtering air and sequestering carbon extend far beyond the boundaries of the park [14]. Clearly, it is recognized that National Parks are a public good that should be established and maintained by government; however, the failure to appreciate the total value of our parks is resulting in an underinvestment in parks and their supporting infrastructure.

The intent of ecosystem service valuation is not to put a "price tag" on these services or suggest they should be commodified. In fact, one purpose of ecosystem service analysis is to show how our wild places produce value that can be thought of 'in dollars' to those who are unable to frame nature conservation as "a moral issue" [17]. Critics who assume that ecosystem service values are expressed in monetary units for the sake of pricing them for commodification are mistaken; while the values could be expressed in terms of time, energy, or land, these units may not be easily understood by a large audience, particularly those in decision-making positions [7]. It is dangerously naïve to promote a moral path (e.g., 'nature is infinitely valuable') as the primary argument for protecting nature. Of course nature has intrinsic value; however, a collective mindset of this nature has not yet developed sufficiently to influence policymakers. In the meantime, "Appeals to people's wallets" may enhance the survival of our National Parks [18].

The National Parks are often regarded as natural capital; however, most of the deferred maintenance making up a $\$ 12$ billion backlog of work weighing down on the National Park Service relates to crumbling infrastructure [18]. This built infrastructure is a poignant example of how our enjoyment of the parks manifests from an interaction of people, infrastructure, and nature (e.g., Human, Social, Built, and Natural Capital). Typically, property management costs range from $30-50 \%$ of the gross rental revenue of a property. If the value of ecosystem services provided by the parks were regarded as a component of the true revenue structure of the National Park Service we could justify a much larger operating budget for the NPS. Currently, the National Park Service's budget is less than $5 \%$ of the annual ecosystem service value of the 46 National Parks involved in this study alone. The National Park service is allotted $\$ 2.8$ billion a year to distribute between 417 sites [4]. After celebrating their Centennial in 2016, the National Park Service recommitted "to exemplary stewardship and public enjoyment" [18]. In order to accomplish this, the National Parks will require increased financial support. A benefits transfer analysis of Yellowstone and Grand Teton National Parks found their combined annual ecosystem service valuation to be $\$ 1.4$ billion/year, meaning two parks return 
half of the value of what is spent on the entire system every year [19]. Ecosystem service valuation is a tool that may be used to justify increased financial resources for wild spaces, which provide many more benefits to society than meet most politicians' eyes.

\section{Materials and Methods}

Boundary information for the National Parks was taken from the National Park Service's GIS database (https:/ / irma.nps.gov / DataStore/). The dataset includes all areas the National Park Service (NPS) is responsible for. We focused the scope of the project to only those components of the NPS that were actual National Parks (does not include national monuments, wild and scenic rivers, etc.). Additionally, National Parks outside of the 48 contiguous states were excluded. There were ultimately 46 National Parks included in this ecosystem service valuation.

The National Land Cover Database (NLCD 2011) contains the most recent land cover information at 30-meter spatial resolution for the United States. The dataset uses a 16-class land cover classification scheme derived from a combination of Landsat and supplementary imagery [20]. The biome types used for the final ecosystem service valuation were taken from Costanza et al.'s framework [7]. The ecosystem service values were estimates based on 17 types of ecosystem services using a benefits transfer method. This approach makes simplifying assumptions about spatial dependence, ecosystem function, and transferability of value [19]. Nonetheless, we argue that these estimates of ecosystem service values are likely underestimates and are plausible and defensible as they are based on thousands of existing peer-reviewed ecosystem service valuations that exist in the TEEB database [1].

NLCD raster data were extracted to the National Park boundaries. Land cover types were reclassified to the biome type they most closely fit (Appendix B for the land cover reclassification scheme). The resulting table for the National Parks produced an area estimate for each biome type within each park. Benefits transfer assumes the value of a wetland in Florida is the same as the value of a wetland in Virginia. To calculate total value of the ecosystems of each park we simply multiplied the biome specific value (Appendix B) by the areal extent of that biome in the park and summed across biomes.

\section{Results}

The areal extent and annual ecosystem service value of each National Park is summarized (Tables 1 and A1). The resulting total estimate of the annual value of the ecosystem services of the National Parks is $\$ 98,694,393,676$ per year. Everglades National Park has the greatest annual ecosystem service value at $\$ 50$ billion per year. It has the greatest spatial extent of tidal marsh and mangrove biome types, as well as the greatest spatial extent of swamps and floodplains. It is the third-largest National Park by area. The National Park with the lowest annual ecosystem service value is Hot Springs National Park in Arkansas. It is also the smallest National Park by area at just 2200 hectares.

The 10 National Parks with the lowest ecosystem service valuations have a few traits in common. Firstly, they have very little water compared to parks with higher ecosystem service values. They also have very little marsh or swamp land cover. These three biome types provide higher value ecosystem services than others. The 10 parks with the lowest ecosystem service valuations are in arid parts of the country. The three National Parks with the highest annual ecosystem service values are the Everglades, Yellowstone, and Death Valley, respectively. They are also the three largest parks by area. 
Table 1. The area and annual ecosystem service values of the National Parks in the conterminous United States.

\begin{tabular}{|c|c|c|}
\hline Park Name & Park Area (ha) & Total ESV (2016\$/ha/y) \\
\hline Acadia & 15,699 & $378,887,375$ \\
\hline Arches & 30,942 & $204,204,501$ \\
\hline Badlands & 98,517 & $216,693,321$ \\
\hline Big Bend & 328,701 & $1,778,630,727$ \\
\hline Biscayne & 67,875 & $1,810,954,914$ \\
\hline Black Canyon of the Gunnison & 12,689 & $58,684,728$ \\
\hline Bryce Canyon & 14,564 & $60,964,780$ \\
\hline Canyonlands & 135,541 & $1,017,166,042$ \\
\hline Capitol Reef & 98,788 & $366,054,464$ \\
\hline Carlsbad Caverns & 18,937 & $90,972,557$ \\
\hline Channel Islands & 99,132 & $957,856,136$ \\
\hline Congaree & 9815 & $2,058,402,071$ \\
\hline Crater Lake & 73,566 & $368,448,820$ \\
\hline Cuyahoga Valley & 13,519 & $260,027,212$ \\
\hline Death Valley & $1,376,357$ & $6,442,495,192$ \\
\hline Dry Tortugas & 25,081 & $395,739,182$ \\
\hline Everglades & 622,662 & $49,466,632,189$ \\
\hline Glacier & 407,920 & $1,816,885,089$ \\
\hline Grand Canyon & 488,719 & $2,228,968,985$ \\
\hline Grand Teton & 125,410 & $1,353,786,050$ \\
\hline Great Basin & 31,239 & $131,690,319$ \\
\hline Great Sand Dunes & 32,745 & $236,529,676$ \\
\hline Great Smoky Mountains & 209,826 & $980,498,972$ \\
\hline Guadalupe Mountains & 35,566 & $162,572,601$ \\
\hline Hot Springs & 2214 & $10,356,998$ \\
\hline Isle Royale & 222,438 & $5,145,696,578$ \\
\hline Joshua Tree & 321,049 & $1,466,536,890$ \\
\hline Kings Canyon & 185,839 & $577,918,285$ \\
\hline Lassen Volcanic & 43,425 & $198,473,270$ \\
\hline Mammoth Cave & 20,777 & $188,981,715$ \\
\hline Mesa Verde & 21,723 & $118,863,815$ \\
\hline Mount Rainier & 95,197 & $530,773,576$ \\
\hline North Cascades & 202,767 & $869,959,499$ \\
\hline Olympic & 369,955 & $2,723,836,053$ \\
\hline Petrified Forest & 90,301 & $450,290,532$ \\
\hline Redwood & 46,799 & $300,054,179$ \\
\hline Rocky Mountain & 108,021 & $650,437,132$ \\
\hline Saguaro & 37,819 & $182,023,394$ \\
\hline Sequoia & 164,710 & $581,911,493$ \\
\hline
\end{tabular}


Table 1. Cont.

\begin{tabular}{ccc}
\hline Park Name & Park Area (ha) & Total ESV (2016\$/ha/y) \\
\hline Shenandoah & 78,217 & $354,510,977$ \\
\hline Theodore Roosevelt & 28,484 & $320,140,985$ \\
\hline Voyageurs & 82,779 & $3,098,987,587$ \\
\hline Wind Cave & 11,462 & $55,255,383$ \\
\hline Yellowstone & 890,092 & $6,554,214,176$ \\
\hline Yosemite & 301,643 & $1,223,899,211$ \\
\hline Zion & 59,928 & $\mathbf{2 4 7 , 5 2 6 , 0 6 3}$ \\
\hline Totals & $\mathbf{7 , 7 5 9 , 4 4 8}$ & $\mathbf{9 8 , 6 9 4 , 3 9 3 , 6 9 4}$ \\
\hline
\end{tabular}

Grasslands and forest are dominant biomes in terms of areal extent of the National Parks (Figure 1). Grass/Rangeland is the most prevalent biome type in the National Parks, while cropland was the least. The land cover classification scheme used in this analysis is given in Table A2. "Desert," "Tundra," and "Ice/Rock" are the only three biome types with an ecosystem service value of $\$ 0$. This is merely a reflection of lack of data in the TEEB database rather than a reflection of low value for those biomes. Clearly Desert, Tundra, and Ice/Rock perform valuable ecosystem services for which we, as of yet, lack a substantial number of peer-reviewed assessments. This is another reason we can regard our estimates as conservative if not low. Forest is the second most prevalent biome type, and has an ecosystem service value per hectare of $\$ 4446$ per year. Water (Streams, Lakes, and Rivers) is the third most prevalent biome type, and has the third-highest annual ecosystem service value of the biomes considered in this study at $\$ 14,639$ per year. The two most valuable biome types in terms of dollar value of ecosystem services provided do not have substantial spatial extents: Tidal Marsh/Mangroves and Swamp/Floodplains.



Figure 1. The spatial extent of each biome type in the National Parks in the conterminous United States.

Canyonlands Park provides an example of our benefits transfer approach. The NLCD land cover categories (Figure 1) are reclassified to the biomes of the TEEB database (Figure 2). Canyonlands National Park is the 15th-largest park by area out of the 46 parks analyzed. Canyonlands NP is in 
arid, southeastern Utah, near Arches National Park. The area is famous for its rusty red rocks and other-worldly rock formations. The Green and Colorado Rivers converge in the park. The dominating land cover type for Canyonlands National Park is "Shrub/Scrub," followed by "Desert" (Figure 1). The most prevalent biome type is "Grass/Rangeland," followed by "Desert" (Figure 2). The rivers support some wetland biomes, which constitute around $45 \%$ of the park's total annual ecosystem service value. The ecosystem service value of Canyonlands National Park is $\$ 1,017,166,041$ per year.

Everglades National Park, located on the southern tip of Florida, is also a World Heritage Site thanks to its unparalleled biodiversity. Figure 3 shows extensive "Water," "Woody Wetlands," and "Emergent Herbaceous Wetlands" land cover types. 99\% of the biome types at the park are "Marsh," "Swamp," or "Water," shown in Figure 3. The ecosystem service value of Everglades National Park, about $\$ 50$ billion per year, constitutes more than half of the ecosystem service value of all the National Parks combined. The value of water ecosystem services account for $6 \%$ of the park's total annual ecosystem service valuation, while wetlands account for around $94 \%$ of the park's total valuation.

North Cascades National Park in Washington is mountainous and home to hundreds of glaciers. The footprint of the mountain range is visible in Figures 4 and 5, which shows the land cover data of the park. The annual ecosystem service value of North Cascades National Park is $\$ 869,959,499$ per year. It is the 12th-largest park by area in this study. North Cascades has one of the largest spatial extents of the "Forest" biome type out of all the National parks studied. The forest biome accounts for $50 \%$ of the park's total ecosystem service valuation and covers just under $50 \%$ of the park. Around $5 \%$ of the park is covered by "Perennial Ice/Snow." While marshes cover less than $1 \%$ of the park's land, they make up nearly $16 \%$ of the park's annual ecosystem service valuation.

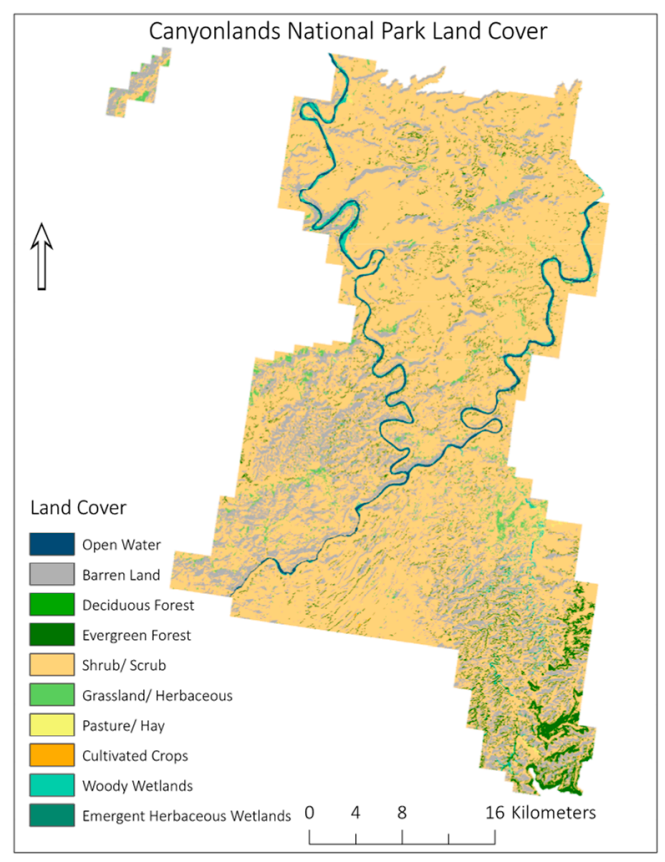

(a)

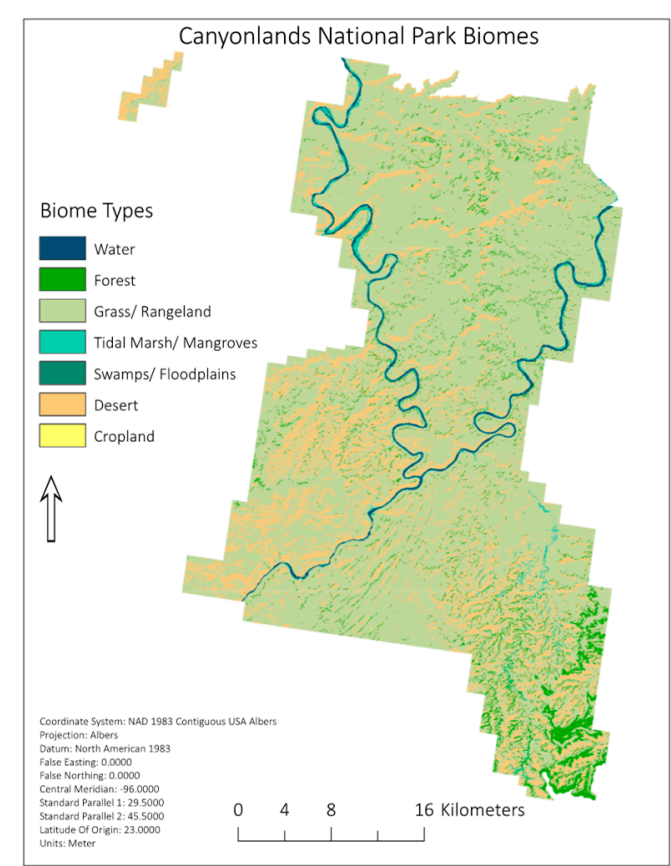

(b)

Figure 2. Land cover (NLCD) and Biomes (ESV) for Canyonlands National Park. 

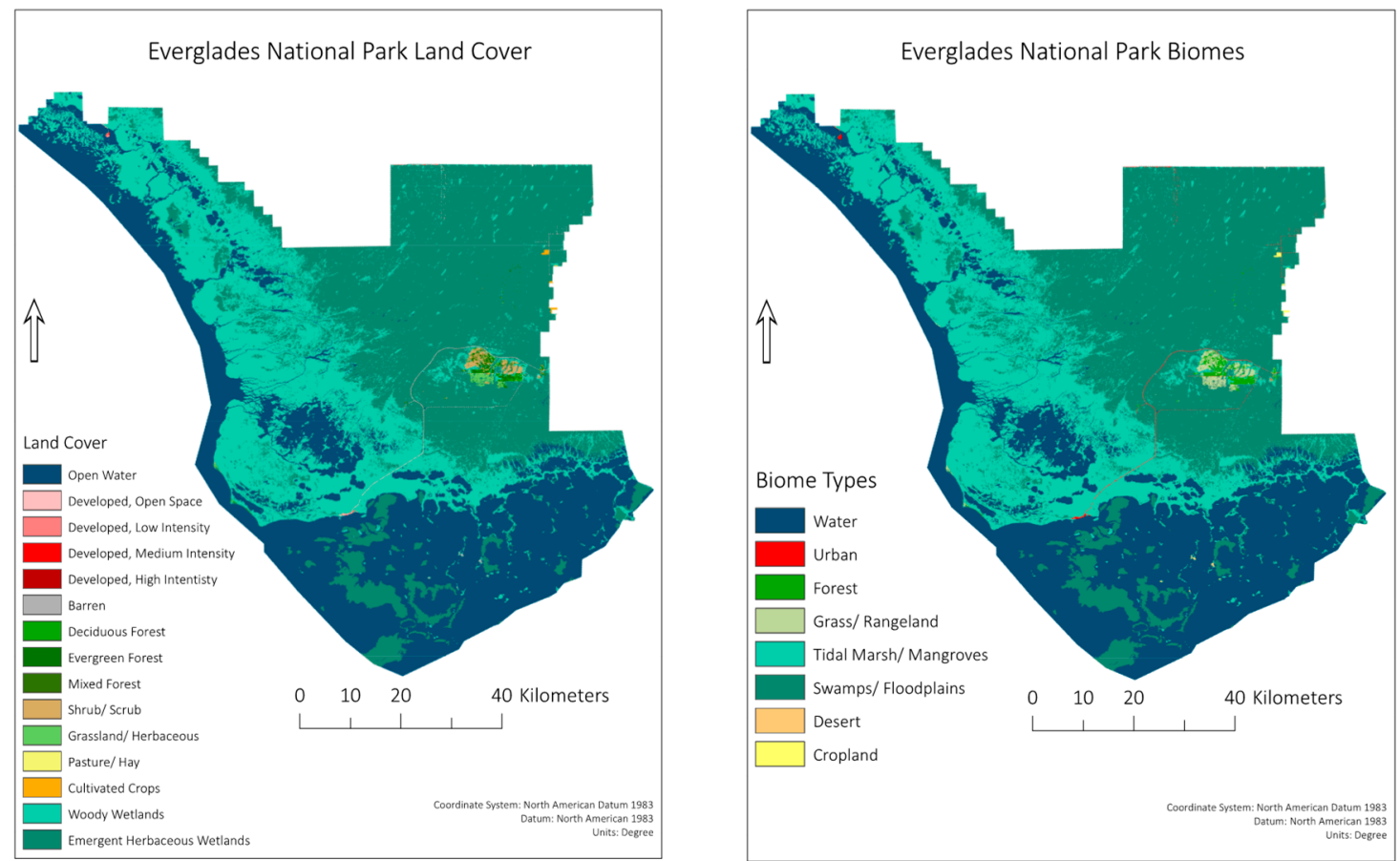

Figure 3. Everglades National Park Land Cover and Biomes.

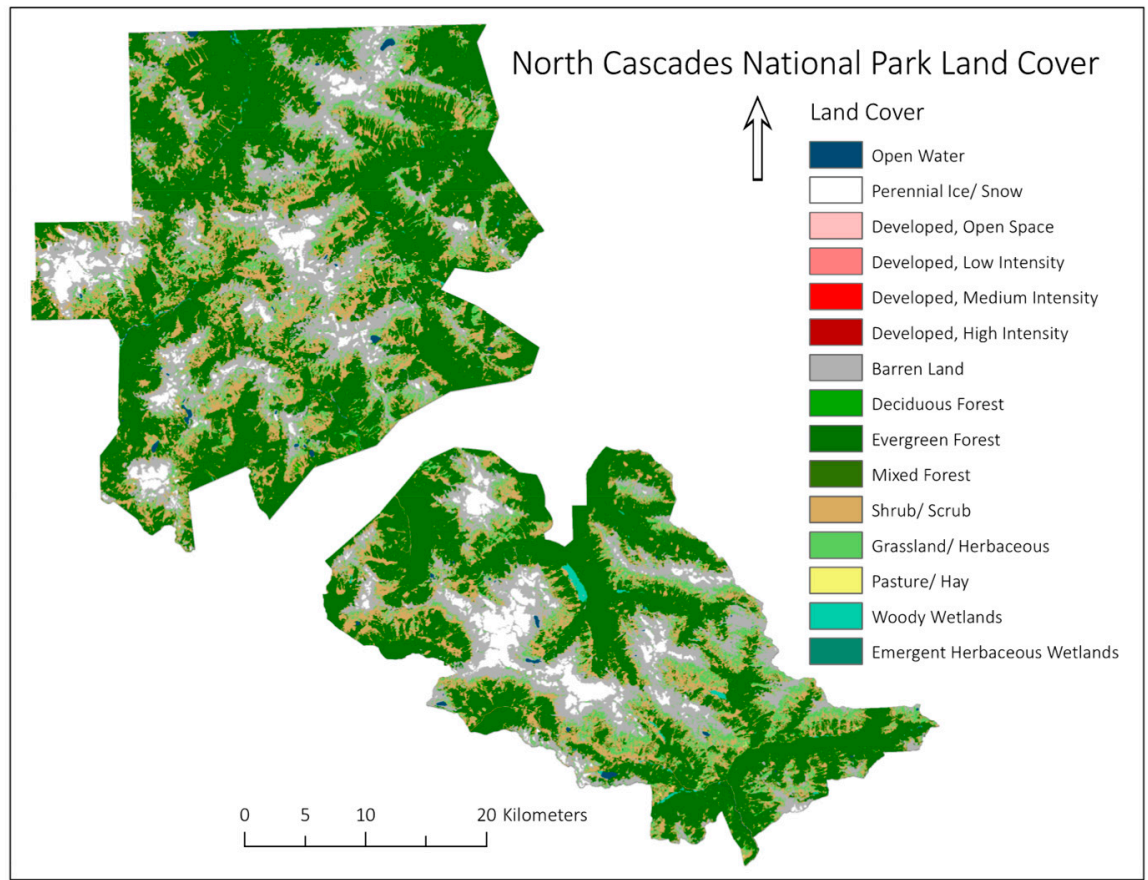

Figure 4. North Cascades National Park land cover map. 


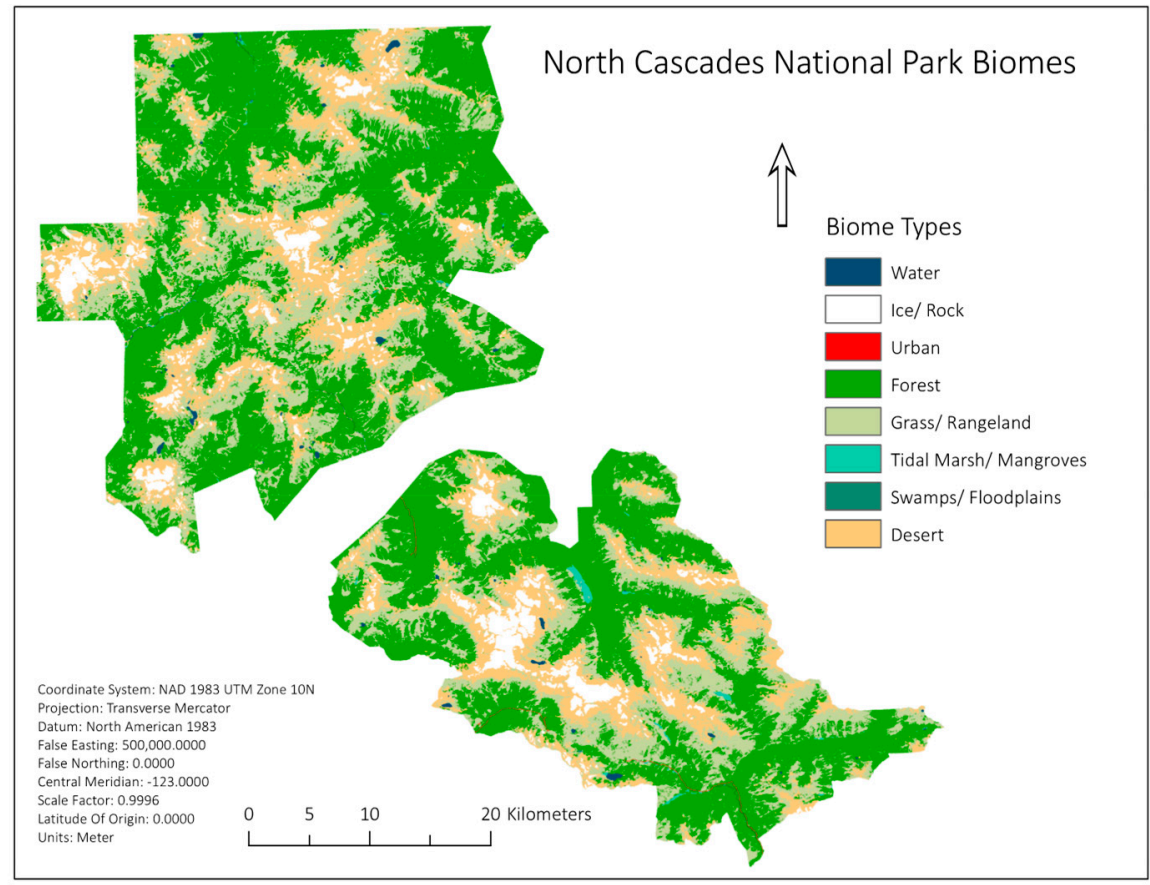

Figure 5. North Cascades National Park biome types.

There are many issues associated with the reduction of the NLCD classes to the biomes of the TEEB. The most abundant biome in the parks was "Grass/Rangeland." This is partially due to the classification of land cover types. Death Valley National Park has more pixels classified as "Grass/Rangeland" than any other park by a factor of 10, while most people know Death Valley is America's most famous desert. The NLCD calls "Shrub/Scrub" a land cover type where vegetation is "less than 5 meters tall ... stunted from environmental conditions" [20]. This land cover type was characterized as the "Grass/Rangeland" biome type because we see this type of vegetation in grasslands, in the alpine, and in deserts. Similarly, the "Barren" land cover type includes scarps, glacial debris, talus, and slides, as well as desert pavement and sand dunes, which are found in desert and alpine landscapes. The "Barren" land cover type was reclassified to "Desert." This oversimplification means "Desert" biomes were reported in alpine areas where a visual analysis might show a different biome type. This limitation did not ultimately affect the results of the valuation because "Desert" biomes are currently valued at zero dollars. These issues of classification are challenging and introduce a variety of uncertainties into analyses of this type.

\section{Discussion}

There are many potential criticisms of these valuations from a technical point of view. Ecosystem service values for the same biome vary spatially [9]. The ecosystem service values used here were intended for a global scale, and even regionally specific ecosystem service values would not be as accurate as ecosystem service values specific to each National Park [21]. The spatial resolution of the data means not all variation in land cover within the parks was captured [22]. These sources of error could result in higher or lower estimates of the National Parks' ecosystem service values. Other errors may have arisen from the reclassification of the biomes from the NLCD data [20,23].

For example, there was no distinction between forest types or marine vs. freshwater biomes. Thus, all types of "forest" were simplified to a single forest ecosystem service average, and all water land cover was assigned the "river/lake" ecosystem service value because there is more freshwater in the National Parks than saltwater [24]. Conversely, the land cover dataset returned different levels of intensity for urban land cover. The ecosystem service value dealing with urban land cover from Costanza et al. does not make this distinction, so all levels of urban development were assigned 
the same ecosystem service value. This study did not incorporate a recent urban ecosystem service valuation of New York City's Central Park, which is currently the highest estimate of per-hectare ecosystem service value ever published (\$70 million per hectare per year) [25]. This astronomical estimate of urban ecosystem service value was not included in this study and would not have mattered much because there is very little urban area within the parks. This estimate of Central Park's ecosystem services is very high because the value results from the significant interaction of human, social, built, and natural capital that exists in Central Park. A study conducted by researchers at Colorado State and Harvard surveyed Americans as to what they would pay for the preservation of the parks. Their estimate of the total annual value of our National Parks was $\$ 62$ billion/year. This estimate is likely also amplified by the significant interaction of human, social, built, and natural capital that takes place in the parks.

The take home point of this study is that a plausible and conservative estimate of the value of the ecosystem services provided by the lands within the United States National Parks is roughly $\$ 98$ billion/year. This estimate is in line with the CSU-Harvard (NPS-TEV) study that estimated the annual value of the National parks at $\$ 62$ billion/year [26]. The $\$ 62$ billion figure was based primarily on analysis of surveys that asked Americans what they would be willing to pay on an annual basis in addition to their existing taxes to preserve the park system and its programs. In fact, the NPS_TEV study validates the idea that our estimate is conservative because we include many ecosystem services that are not well perceived by the public [2].

Ongoing land degradation, climate change, ocean acidification, and land cover changes are reducing the quantity and quality of ecosystem services being provided globally [4,5]. These losses are taking place because we do not value ecosystem services at a sufficient level to preserve them. Many individuals, NGOs, and nations are progressively more involved in studies, legislation, and increasingly urgent expressions of concern regarding damage to the world's environment that is ongoing and likely accelerating [27-29].

A primary reason for this loss of natural capital is our collective inability to appropriately value our natural environment. Valuations of ecosystem services that eclipse the dollar size of market economies are regarded as not credible by some (particularly economists); however, there is growing consensus that our market-based economic systems have failed to serve as rational stewards of the environment [30]. We present these numbers as a reasonable starting place to discuss a new allocation of resources in which we preserve the ability of our environment to support our society, economy, and individual wellbeing. We regard plausible valuation of ecosystem services as a good starting point for environmental politics [31] and suggest that discussions of levels of funding for our national parks is fundamentally in the domain of environmental politics and the institutional changes suggested are compatible with ideas expressed in 'The Green New Deal'.

In addition, this study only included areas under the National Park Service's "National Park" classification. Of course, most, if not all, areas they manage provide ecosystem services, from historical battlefields to recreation areas to lakeshores. This study only included National Park areas within the contiguous 48 states. There are several National Parks in Alaska, American Samoa, the U.S. Virgin Islands, Puerto Rico, and Hawaii that were not considered in this study, including the largest National Park in the system, Wrangell-St. Elias National Park, which is 5.37 million hectares [4].

Even if the ecosystem service values were overestimated in this study, a lower estimated value would be considerably higher than the amount spent on the National Parks by the federal government. More importantly, only a small fraction of the areas maintained by the National Park Service were analyzed in this study. A study done of ecosystem service values of all the wild spaces managed by the Park Service would undoubtedly return an even higher value. Given that the annual budget of the National Park service is around $\$ 3$ billion, and the value of the associated ecosystem services is more than 28 times that, we suggest they are grossly underfunded in terms of return on investment. If we regarded the National Parks as more than a revenue stream generated by visitors, and rather as natural capital generating a revenue stream of ecosystem services that have significant monetary 
value, it is likely that greater investments in the National Parks would be less controversial. If the National Parks were treated as built capital, and we used annual ecosystem services alone to account for gross revenue, we would provide at least $\$ 27$ billion for an operating budget ( $30 \%$ of $\$ 98$ billion) according to industry standard property management fees.

Critics like Douglas McCauley argue that market-based conservation strategies do not work. He argues "market-based mechanisms for conservation are not a panacea for our current conservation ills"; however, ecosystem services bridge the gap between pragmatic economics and optimistic environmentalism [17]. Assuming that the goal of ecosystem service valuation is to prove that "nature is only worth conserving when it is, or can be made profitable" is in fact the opposite of the purpose of this type of analysis [17]. Until our collective mindset develops to place value on unimpaired nature such that conservation and preservation are considered moral imperatives, ecosystems services are a tool that can be used to justify protecting our environment.

\section{Conclusions}

In this paper we present a valuation of the United States National Parks from an ecological economics perspective. We used a simple direct benefits transfer approach using biome values from the TEEB database and landcover measures from the USGS National Land Cover Dataset to estimate the value of the ecosystem services of the 46 National Parks in the contiguous United States to estimate the annual value of ecosystem services provided by the lands within the United States National Park System. Our estimate of $\$ 98$ billion/year is a holistic aggregate estimate of the provisioning, regulating, supporting, and cultural services provided by the functioning ecosystems of the parks. This estimate is surprisingly consistent with an entirely independent and methodologically distinct estimate of $\$ 62$ billion/year derived from surveys of the American public that asked how much additional taxes they would be willing to pay for the parks [4]. If the natural capital 'asset' of infrastructure that is our national park system had a budget comparable to a piece of commercial real estate of this value, the annual budget of the National Park Service would be roughly an order of magnitude larger at something closer to $\$ 30$ billion rather than $\$ 3$ billion. We do not make estimates of this nature to commodify our natural treasures. We make these estimates because our failure to consider the total value of ecosystem services provided by the National Parks enables our inability to quantify and appreciate the contributions our parks make to our environment, economy, and society. These kinds of oversights allow us to continue to underfund a valuable part of our natural capital and consequently damage our supporting environment, national heritage, monetary economy, and many of our diverse cultures. Ecological economics argues for several specific changes to the dominant economic paradigm including changing the degree to which we invest in the stewardship of our collectively held natural capital assets. Three guiding principles inform the broader level institutional and policy changes we argue are needed. First, we must live within planetary boundaries (e.g., there are limits to growth, earth is a finite planet, etc.). Second, we must equitably distribute wealth and income throughout space and time (e.g., meet a John Rawls 'veil of ignorance' test). Third, we must allocate resources efficiently (e.g., traditional economics associated with maximizing utility through resource allocation). Living within planetary boundaries is primarily an assessment of scientists who have expertise that is relatively objective. In this area Richard Feynman's quote seems appropriate: "Reality must take precedence over public relations, for nature cannot be fooled" [32,33]. The current scientific consensus suggests we are failing to meet the standard of the first principle. Equitable distribution is a messier question involving public relations and social negotiations. A growing literature on the negative consequences of inequality $[34,35]$ and social movements (e.g., Occupy Wall Street, The Women's March, Black Lives Matter) suggests we are also failing to meet the standard of the second principle. The third principle of optimal allocation is working in a limited way through the dominant economic paradigm; however, it also fails because it is not subservient to the first two principles and results in inadequate resource valuation, misallocation, short-termism, and unacceptable levels of inequality and poverty [5,31]. Recognizing the ecosystem service value of our national parks and increasing the 
budget of the NPS to support and maintain the parks and monuments is a small step we could make towards living within the guiding principles of ecological economics. This would also be a significant step towards many of the visions of a 'green new deal'. Our National parks are a significant element of the fundamental supporting environment that our society, economy and our very lives depend on. Increased funding of our National Parks will not only create jobs that sustain and preserve these significant values but will also help us chart a path to a more sustainable and desirable future.

Author Contributions: Conceptualization, P.C.S, S.L.D., and S.J.A.; methodology, S.L.D., and S.J.A.; validation, P.C.S; data curation, P.C.S.; writing-original draft preparation, S.L.D.; writing-review and editing, P.C.S and S.J.A.; visualization, S.L.D. and S.J.A.; supervision, P.C.S; project administration, P.C.S.

Funding: This research received no external funding.

Conflicts of Interest: The authors declare no conflict of interest. 


\section{Appendix A}

Table A1. Detailed National Park biome extent and ecosystem service value.

\begin{tabular}{|c|c|c|c|c|c|c|c|c|c|c|c|c|}
\hline UNIT_NAME & Water & Ice/Rock & Urban & Forest & Grass/Rangeland & Tidal Marsh/Mangroves & Swamp/Floodplains & Desert & Tundra & Cropland & $\begin{array}{c}\text { Park Area } \\
\text { (pixels) }\end{array}$ & $\begin{array}{l}\text { Park Area } \\
\text { (hectares) }\end{array}$ \\
\hline Acadia & 5411 & 0 & 9292 & 123,491 & 2973 & 14,547 & 4359 & 1128 & 13,237 & 0 & 174,438 & $15,699.42$ \\
\hline Arches & 129 & 0 & 1945 & 3649 & 8489 & 3381 & 0 & 33,342 & 292,866 & 0 & 343,801 & $30,942.09$ \\
\hline Badlands & 667 & 0 & 8670 & 3417 & 454,772 & 260 & 59 & 620,891 & 364 & 5528 & $1,094,628$ & $98,516.52$ \\
\hline Big Bend & 592 & 0 & 13,617 & 61,261 & 708 & 9107 & 852 & 21,574 & $3,541,998$ & 2525 & $3,652,234$ & $328,701.06$ \\
\hline Biscayne & 563,075 & 0 & 87 & 1617 & 0 & 31,414 & 157,966 & 0 & 6 & 0 & 754,165 & $67,874.85$ \\
\hline $\begin{array}{l}\text { Black Canyon of the } \\
\text { Gunnison }\end{array}$ & 274 & 0 & 74 & 93,569 & 1232 & 15 & 0 & 270 & 45,556 & 0 & 140,990 & $12,689.1$ \\
\hline Bryce Canyon & 0 & 0 & 3324 & 110,872 & 1131 & 189 & 0 & 23,705 & 22,602 & 0 & 161,823 & $14,564.07$ \\
\hline Canyonlands & 22,003 & 0 & 0 & 74,053 & 35,496 & 22,470 & 385 & 249,960 & $1,101,548$ & 95 & $1,506,010$ & $135,540.9$ \\
\hline Capitol Reef & 30 & 0 & 3951 & 127,690 & 83,286 & 871 & 0 & 294,068 & 587,753 & 0 & $1,097,649$ & $98,788.41$ \\
\hline Carlsbad Caverns & 0 & 0 & 751 & 39,720 & 4039 & 0 & 0 & 12 & 165,833 & 56 & 210,411 & $18,936.99$ \\
\hline Channel Islands & 533,575 & 0 & 3099 & 6283 & 249,625 & 63 & 3891 & 11,180 & 293,751 & 0 & $1,101,467$ & $99,132.03$ \\
\hline Congaree & 1012 & 0 & 296 & 6257 & 185 & 100,543 & 746 & 0 & 13 & 5 & 109,057 & 9815.13 \\
\hline Crater Lake & 58,536 & 0 & 7589 & 673,537 & 6422 & 0 & 0 & 40,132 & 31,179 & 0 & 817,395 & $73,565.55$ \\
\hline Cuyahoga Valley & 2707 & 0 & 18,174 & 108,180 & 8444 & 9539 & 107 & 44 & 298 & 2721 & 150,214 & $13,519.26$ \\
\hline Death Valley & 51 & 0 & 33,476 & 361,922 & 30,894 & 2803 & 13 & 722,864 & $14,140,625$ & 205 & $15,292,853$ & $1,376,356.77$ \\
\hline Dry Tortugas & 259,100 & 0 & 5 & 0 & 63 & 123 & 19,142 & 131 & 0 & 112 & 278,676 & $25,080.84$ \\
\hline Everglades & $2,307,344$ & 0 & 9504 & 20,944 & 11,639 & $1,925,627$ & $2,622,794$ & 1554 & 16,916 & 2148 & $6,918,470$ & $622,662.3$ \\
\hline Glacier & 117,536 & 46,159 & 7964 & $2,741,088$ & 107,346 & 2675 & 537 & 468,561 & $1,040,579$ & 0 & $4,532,445$ & $407,920.05$ \\
\hline Grand Canyon & 35,140 & 0 & 12,811 & $1,105,126$ & 134,396 & 8640 & 2033 & 734,016 & $3,397,942$ & 104 & $5,430,208$ & $488,718.72$ \\
\hline Grand Teton & 142,499 & 4433 & 10,756 & 464,974 & 233,968 & 29,401 & 31,702 & 56,384 & 419,326 & 6 & $1,393,449$ & $125,410.41$ \\
\hline Great Basin & 32 & 1157 & 992 & 292,141 & 5744 & 156 & 5 & 27,871 & 19,006 & 0 & 347,104 & $31,239.36$ \\
\hline Great Sand Dunes & 255 & 0 & 1855 & 13,014 & 17,536 & 5257 & 6377 & 97,435 & 222,017 & 84 & 363,830 & $32,744.7$ \\
\hline Great Smoky Mountains & 18,391 & 0 & 21,367 & $2,269,789$ & 10,720 & 1188 & 0 & 773 & 8657 & 510 & $2,331,395$ & $209,825.55$ \\
\hline Guadalupe Mountains & 8 & 0 & 952 & 85,301 & 3483 & 0 & 0 & 17,677 & 287,759 & 0 & 395,180 & $35,566.2$ \\
\hline Hot Springs & 5 & 0 & 1715 & 22,670 & 174 & 0 & 0 & 34 & 0 & 0 & 24,598 & 2213.82 \\
\hline Isle Royale & $1,870,766$ & 0 & 0 & 448,294 & 245 & 121,032 & 9222 & 8189 & 13,782 & 0 & $2,471,530$ & $222,437.7$ \\
\hline Joshua Tree & 0 & 0 & 12,621 & 5652 & 59,573 & 0 & 0 & 231,209 & $3,258,161$ & 0 & $3,567,216$ & $321,049.44$ \\
\hline Kings Canyon & 23,516 & 2385 & 3785 & 581,351 & 111,260 & 283 & 2238 & 767,848 & 572,189 & 26 & $2,064,881$ & $185,839.29$ \\
\hline Lassen Volcanic & 8664 & 0 & 5657 & 345,800 & 1019 & 0 & 827 & 24,702 & 95,830 & 0 & 482,499 & $43,424.91$ \\
\hline
\end{tabular}


Table A1. Cont.

\begin{tabular}{|c|c|c|c|c|c|c|c|c|c|c|c|c|}
\hline UNIT_NAME & Water & Ice/Rock & Urban & Forest & Grass/Rangeland & Tidal Marsh/Mangroves & Swamp/Floodplains & Desert & Tundra & Cropland & $\begin{array}{c}\text { Park Area } \\
\text { (pixels) }\end{array}$ & $\begin{array}{l}\text { Park Area } \\
\text { (hectares) }\end{array}$ \\
\hline Mammoth Cave & 2182 & 0 & 573 & 221,925 & 1252 & 4695 & 187 & 0 & 37 & 0 & 230,851 & $20,776.59$ \\
\hline Mesa Verde & 79 & 0 & 2766 & 79,019 & 24,608 & 764 & 22 & 177 & 133,929 & 0 & 241,364 & $21,722.76$ \\
\hline Mount Rainier & 7031 & 126,222 & 8714 & 666,369 & 26,864 & 8912 & 82 & 88,538 & 125,016 & 0 & $1,057,748$ & $95,197.32$ \\
\hline North Cascades & 7252 & 105,505 & 1158 & $1,103,359$ & 245,528 & 6788 & 326 & 393,359 & 389,693 & 0 & $2,252,968$ & $202,767.12$ \\
\hline Olympic & 75,640 & 152,584 & 11,437 & $3,254,129$ & 57,632 & 56,695 & 1876 & 212,356 & 288,264 & 0 & $4,110,613$ & $369,955.17$ \\
\hline Petrified Forest & 182 & 0 & 5804 & 17 & 117,151 & 468 & 28 & 2182 & 877,467 & 44 & $1,003,343$ & $90,300.87$ \\
\hline Redwood & 34,301 & 0 & 14,380 & 439,656 & 8977 & 2756 & 1151 & 6289 & 11,971 & 504 & 519,985 & $46,798.65$ \\
\hline Rocky Mountain & 3115 & 152,940 & 10,514 & 672,286 & 164,871 & 13,775 & 4028 & 166,024 & 12,677 & 0 & $1,200,230$ & $108,020.7$ \\
\hline Saguaro & 37 & 0 & 4402 & 92,035 & 168 & 7 & 0 & 220 & 323,342 & 0 & 420,211 & $37,818.99$ \\
\hline Sequoia & 9923 & 368 & 5913 & 841,408 & 75,860 & 0 & 1981 & 462,970 & 431,691 & 0 & $1,830,114$ & $164,710.26$ \\
\hline Shenandoah & 5 & 0 & 22,694 & 846,030 & 127 & 0 & 0 & 217 & 0 & 1 & 869,074 & $78,216.66$ \\
\hline Theodore Roosevelt & 3561 & 0 & 4577 & 62,324 & 174,027 & 9049 & 3090 & 20,104 & 36,641 & 3111 & 316,484 & $28,483.56$ \\
\hline Voyageurs & 330,347 & 0 & 609 & 420,308 & 384 & 116,484 & 41,793 & 0 & 9809 & 35 & 919,769 & $82,779.21$ \\
\hline Wind Cave & 0 & 0 & 2317 & 38,807 & 60,730 & 0 & 122 & 0 & 25,374 & 0 & 127,350 & $11,461.5$ \\
\hline Yellowstone & 465,177 & 351 & 29,519 & $4,541,815$ & 926,547 & 79,247 & 178,931 & 31,545 & $3,636,782$ & 0 & $9,889,914$ & $890,092.26$ \\
\hline Yosemite & 31,871 & 2380 & 14,152 & $1,687,611$ & 118,943 & 33 & 15,992 & 567,413 & 913,173 & 24 & $3,351,592$ & $301,643.28$ \\
\hline Zion & 0 & 0 & 4657 & 330,871 & 329 & 722 & 49 & 108,461 & 220,778 & 0 & 665,867 & $59,928.03$ \\
\hline Total Pixel Count & $6,942,021$ & 594,484 & 338,515 & $25,489,631$ & $3,588,860$ & $2,589,979$ & $3,112,913$ & $6,515,409$ & $37,026,437$ & 17,844 & $86,216,093$ & $86,216,093$ \\
\hline Area in Hectares & 624,782 & 53,504 & 30,466 & $2,294,067$ & 322,997 & 233,098 & 280,162 & 586,387 & $3,332,379$ & 1606 & $7,759,448$ & $7,759,448$ \\
\hline \multicolumn{13}{|l|}{${ }^{*} \mathrm{I}$ pixel $=900 \mathrm{~m}^{2}=0.09 \mathrm{Ha}$} \\
\hline $\begin{array}{l}\text { Area in square kilometers } \\
\left(\mathrm{km}^{2}\right)\end{array}$ & 6248 & 535 & 305 & 22,941 & 3230 & 2331 & 2802 & 5864 & 33,324 & 16 & 77,594 & 77,594 \\
\hline
\end{tabular}




\section{Appendix B}

Table A2. Land cover reclassification scheme and corresponding ESV.

\begin{tabular}{ccc}
\hline Land Cover Type & Biome Type & ESV (2016\$/ha/yr) \\
\hline Water & Water & 14,639 \\
Perennial Ice/Snow & Ice/Rock & 0 \\
Developed, Open Space & Urban & 7793 \\
Developed, Low Intensity & Urban & 7793 \\
Developed, Medium Intensity & Urban & 7793 \\
Developed, High Intensity & Urban & 7793 \\
Barren Land & Desert & 0 \\
Deciduous Forest & Forest & 4446 \\
Evergreen Forest & Forest & 4446 \\
Mixed Forest & Forest & 4446 \\
Shrub/Scrub & Grass/Rangeland & 4874 \\
Grassland/Herbaceous & Grass/Rangeland & 4874 \\
Pasture/Hay & Grass/Rangeland & 4874 \\
Cultivated Crops & Cropland & 6513 \\
Woody Wetlands & Tidal Marsh/Mangrove & 226,796 \\
Emergent Herbaceous Wetlands & Swamps/Floodplains & 30,047 \\
\hline
\end{tabular}

All dollar values were converted to 2016 dollars using the Bureau of Labor Statistics website. We used the conversion factor of 1.17 for every 2007 dollar. (https: / www.bls.gov / data/inflation calculator.htm last accessed 3/24/2019)

Source for original ecosystem biomes 2007 U.S. dollars [7].

\section{References}

1. TEEB. The Economics of Ecosystems and Biodiversity: Mainstreaming the Economics of Nature: A Synthesis of the Approach, Conclusions and Recommendations of TEEB. 2010. Available online: http:/ /www.teebweb. org/ (accessed on 27 October 2018).

2. Pitman, S.D.; Daniels, C.B.; Sutton, P.C. Characteristics associated with high and low levels of ecological literacy in a western society. Int. J. Sustain. Dev. World Ecol. 2018, 25, 227-237. [CrossRef]

3. PBS. 2016. Available online: http://www.pbs.org/nationalparks/ (accessed on 14 December 2018).

4. Cullinane Thomas, C.; Koontz, L.; Cornachione, E. 2017 National Park Visitor Spending Effects: Economic Contributions to local Communities, States, and the Nation; Natural Resource Report NPS/NRSS/EQD/NRR—2018/1616; National Park Service: Fort Collins, CO, USA, 2018. Available online: https://www.nationalparks.org/sites/default/files/NPS-TEV-Report-2016.pdf (accessed on 14 December 2018).

5. Costanza, R.; Cumberland, J.H.; Daly, H.; Goodland, R.; Norgaard, R.B.; Kubiszewski, I.; Franco, C. An Introduction to Ecological Economics, 2nd ed.; CRC Press: Boca Raton, Fl, USA, 2011.

6. Costanza, R.; D'Arge, R.; De Groot, R.; Farber, S.; Grasso, M.; Hannon, B.; Limburg, K.; Naeem, S.; O'Neill, R.V.; Paruelo, J.; et al. The value of the world's ecosystem services and natural capital. Nature 1997, 387, 253-260. [CrossRef]

7. Costanza, R.; De Groot, R.; Sutton, P.; Van Der Ploeg, S.; Anderson, S.J.; Kubiszewski, I.; Farber, S.; Turner, R.K. Changes in the Global Value of Ecosystem Services. Glob. Environ. Chang. 2014, 26, 152-158. [CrossRef]

8. Costanza, R.; de Groot, R.; Braat, L.; Kubiszewski, I.; Fioramonti, L.; Sutton, P.; Farber, S.; Grasso, M. Twenty years of ecosystem services: how far have we come and how far do we still need to go? Ecosyst. Serv. 2017, 28, 1-16. [CrossRef]

9. Sutton, P. Space matters: Exploring problematic spatial issues in the valuation of ecosystem services. In Valuing Ecosystem Services: Methodological Issues and Case Studies; Ninan, K.N., Ed.; Edward Elgar Publishing: Cheltenham, UK, 2014; pp. 132-147.

10. Sutton, P.C.; Anderson, S.J.; Costanza, R.; Kubiszewski, I. The ecological economics of land degradation: Impacts on ecosystem service values. Ecol. Econ. 2016, 129, 182-192. [CrossRef] 
11. Pitman, S.D.; Daniels, C.B.; Sutton, P.C. Ecological literacy and socio-demographics: who are the most eco-literate in our community, and why? Int. J. Sustain. Dev. World Ecol. 2018, 25, 9-22. [CrossRef]

12. de Groot, R.; Brander, L.; van der Ploeg, S.; Costanza, R.; Bernard, F.; Braat, L.; Christie, M.; Crossman, N.; Ghermandi, A.; Hein, L.; et al. Global estimates of the value of ecosystems and their services in monetary units. Ecosyst. Serv. 2012, 1, 40-61. [CrossRef]

13. Costanza, R.; Hart, M.; Kubiszewski, I.; Posner, S. Lessons from the History of GDP in the Effort to Create Better Indicators of Prosperity, Well-being, and Happiness. In Routledge Handbook of Sustainability Indicators; Routledge: Abingdon, UK, 2018; pp. 147-153.

14. Díaz, S.; Pascual, U.; Stenseke, M.; Martín-López, B.; Watson, R.T.; Molnár, Z.; Hill, R.; Chan, K.M.A.; Baste, I.A.; Brauman, K.A.; et al. Assessing nature's contributions to people. Science 2018, 359, 270-272. [CrossRef] [PubMed]

15. de Groot, R.; Costanza, R.; Braat, L.; Brander, L.; Burkhard, B.; Carrascosa, J.L.; Egoh, B.; Geneletti, D.; Hansjuergens, B.; Hein, L.; et al. Ecosystem Services are Nature's Contributions to People: Response to: Assessing nature's contributions to people. Sci. Prog. 2018, 359, 6373.

16. Daly, H.E.; Farley, J.C. Ecological Economics: Principles and Applications, 2nd ed.; Island Press: Washington, DC, USA, 2011.

17. Mccauley, D.J. Selling out on Nature. Nature 2006, 443, 27-28. [CrossRef] [PubMed]

18. A Call to Action. 2016. Available online: https://www.nps.gov/calltoaction/ (accessed on 25 August 2018).

19. Duncan, S.; Sutton, P.C. An Ecosystem Service Valuation of Yellowstone and Grand Teton National Parks. Presented at the USSEE Conference Macalaster College, Saint Paul, MN, USA, 25-28 June 2017.

20. Homer, C.G.; Dewitz, J.A.; Yang, L.; Jin, S.; Danielson, P.; Xian, G.; Coulston, J.; Herold, N.D.; Wickham, J.D.; Megown, K. Completion of the 2011 National Land Cover Database for the conterminous United States-Representing a decade of land cover change information. Photogramm. Eng. Remote Sens. 2015, 81, 345-354.

21. Anderson, S.; Giordano, A.; Costanza, R.; Kubiszewski, I.; Sutton, P.; Maes, J.; Neale, A. 5.7.2. National ecosystem service mapping approaches. In Mapping Ecosystem Services; Pensoft Publishers: Sofia, Bulgaria, 2017; p. 237.

22. Burhard, B.; Maes, J. Mapping Ecosystem Services; Advanced Books; Pensoft Publishers: Sofia, Bulgaria, 2017. [CrossRef]

23. Wickham, J.; Stehman, S.V.; Gass, L.; Dewitz, J.A.; Sorenson, D.G.; Granneman, B.J.; Poss, R.V.; Baer, L.A. Thematic accuracy assessment of the 2011 National Land Cover Database (NLCD). Remote Sens. Environ. 2017, 191, 328-341. [CrossRef]

24. National Park Service. 2008 Director's Report; National Park Service, U.S. Department of the Interior: Washington, DC, USA, 2009.

25. Sutton, P.C.; Anderson, S.J. Holistic valuation of urban ecosystem services in New York City's Central Park. Ecosyst. Serv. 2016, 19, 87-91. [CrossRef]

26. Haefele, M.; Loomis, J.; Bilmes, L.J. Total Economic Valuation of the National Park Service Lands and Programs: Results of a Survey of The American Public. 2016. Available online: https:/ /www.nationalparks. org/sites/default/ files/NPS-TEV-Report-2016.pdf (accessed on 26 October 2018).

27. IPCC: Climate Change 2013: The Physical Science Basis. Contribution of Working Group I to the Fifth Assessment Report of the Intergovernmental Panel on Climate Change; Stocker, T.F.; Qin, D.; Plattner, G.-K.; Tignor, M.; Allen, S.K.; Boschung, J.; Nauels, A.; Xia, Y.; Bex, V.; Midgley, P.M. (Eds.) Cambridge University Press: Cambridge, UK, 2013.

28. MEA: Millennium Ecosystem Assessment (Program). Ecosystems and Human Well-Being; Island Press: Washington, DC, USA, 2005.

29. United Nations Environment Programme. Global Environment Outlook GEO 5: Environment for the Future We Want; United Nations Environment Program: Nairobi, Kenya, 2012.

30. Lovins, H.; Stewart, W.; Wijkman, A.; Fullerton, J. A Finer Future: Creating an Economy in Service to Life; New Society Press: Vancouver, BC, Canada, 2018.

31. Jadhav, A.; Anderson, S.; Dyer, M.J.; Sutton, P.C. Revisiting ecosystem services: Assessment and valuation as starting points for environmental politics. Sustainability 2017, 9, 1755. [CrossRef]

32. Feynman, R. Appendix F: Personal Observations on the Reliability of the Shuttle. PCSSCA. Volume 11, p. F5. Available online: https:/ / www.refsmmat.com/files/reflections.pdf (accessed on 14 December 2018). 
33. Feynman, R. What do you Care What Other People Think? Further Adventures of a Curious Character; W. W. Norton (US): New York, NY, USA, 1988; p. 237.

34. Wilkinson, R.G.; Pickett, K. The Spirit Level: Why Greater Equality Makes Societies Stronger; Bloomsbury Press: New York, NY, USA, 2010.

35. Piketty, T. Capital in the Twenty-First Century; The Belknap Press of University Press: Cambridge, MA, USA, 2014. 